\title{
Alat Pendingin Ruang Terbuka Yang Efektif Ekonomis Dan Ramah Lingkungan
}

\author{
Widya Fitriana, S.Pd. \\ Email : widyafitriana123@gmail.com
}

\begin{abstract}
ABSTRAK
Lokasi Lamongan yang terletak dekat dengan laut menyebabkan suhu di lamongan cukup panas di siang hari. Kondisi tersebut semakin diperparah dengan adanya dampak pemanasan global yang mengakibatkan planet bumi terus mengalami peningkatan suhu. Mahalnya harga AC dan beban daya listrik AC yang besar menyebabkan sebagian besar masyarakat Lamongan belum banyak yang menggunakan AC. Tujuan dari penelitian ini ialah membuat alat pendingin ruangan yang ramah lingkungan. Metode penelitian yang digunakan perancangan dan pembuatan produk ini digunakan model pengembangan prosedural yang bersifat deskriptif (Shodiq, 2005:32). Hasil dari penelitian bahwa alat pendingin ruang terbuka efektif dapat menurunkan suhu di sekitar pemasangan alat tersebut. Harga bahan penyusunnya yang murah dan tidak menimbulkan dampak negatif terhadap lingkungan.
\end{abstract}

\section{Kata kunci : Pendingin Ruangan, ramah Lingkungan}

\section{PENDAHULUAN}

Lamongan adalah sebuah daerah yang terletak di dataran rendah, lokasi Lamongan yang terletak dekat dengan laut menyebabkan suhu di lamongan cukup panas di siang hari. Tercatat data dari Badan Metereologi dan Geofisika (BMG) menyebutkan bahwa suhu di kabupaten Lamongan mencapai $29^{\circ} \mathrm{C}$ dengan curah hujan rata-rata berkisar sekitar 269 $\mathrm{mm} /$ th. Hal ini mengakibatkan keadaan Lamongan cukup panas di siang dan malam hari.

Kondisi tersebut semakin diperparah dengan adanya dampak pemanasan global yang mengakibatkan planet bumi terus mengalami peningkatan suhu. Meningkatnya suhu global diperkirakan akan menyebabkan perubahanperubahan yang lain seperti naiknya permukaan air laut, meningkatnya intensitas fenomena cuaca yang ekstrim, serta perubahan jumlah dan pola presipitasi. Akibat-akibat pemanasan global yang lain adalah terpengaruhnya hasil pertanian, hilangnya gletser, dan punahnya berbagai jenis hewan.

Untuk menanggulangi keadaan tersebut, beberapa perusahan elektronik menciptakan sebuah alat penkodisian udara atau Air Conditioner (AC) untuk membuat suasana lebih nyaman dan sejuk di dalam ruangan. Dengan harapan suasana yang sejuk dan nyaman akan meningkatkan produktifvitas dan etos kerja karyawan, anggota keluarga, siswa yang berada dalam ruangan.
Mahalnya harga AC dan bevais daya listrik AC yang besar menyebabkan sebagian besar masyarakat Lamongan belum banyak yang menggunakan AC. Di samping itu beberapa AC yang menggunakan $\mathrm{CFC}$ (Cloroflorocarbon), HFC dan HCFC (C-Chloro, F-Fluor, C-Carbon, H-Hydro) atau disini biasa dikenal dengan istilah FREON (Syntetic Refrigerant) dapat menambah percepatan pemanasan global. Hal ini semakin menambah deretan dampak buruk penggunaan AC.

Di samping itu kegunaan AC yang hanya bisa digunakan di ruang tertutup (in door) menuntut untuk diciptakannya alat pendingin ruangan terbuka. Selama ini alat pendingin yang digunakan untuk mendinginkan ruangan terbuka masih konvensional dan tidak efektif. Biasanya masyarakat kita menggunakan kipas angin yang di pasang di langit-langit tenda pesta yang hanya dapat meniupkan angin sehingga kurang dapat menyejukkan ruangan. Ada juga yang membuat alat pendingin dengan membuat tumpukan es sebagai penyedia udara sejuk yang kemudian ditiup menggunakan kipas. Cara tersebut tidak efektif karena es yang digunakan cepat mencair. Masalah lain timbul jika tiupan angin membawa butiran air, yang berakibat basahnya lantai dan ruangan.

Berkaitan dengan keadaan tersebut, diperlukan sebuah alat pendingin udara ruang terbuka (outdoor) yang ekonomis, efektif dan ramah lingkungan. Alat pendingin yang dimaksud haruslah yang mudah dibuat dan murah serta tidak mengakibatkan dampak yang berbahaya terhadap lingkungan sekitar. Penelitian ini bertujuan mengembangkan sebuah 
alat pendingin ruang terbuka yang efektif, ekonomis dan ramah lingkungan.

\section{METODE PENELITIAN}

\section{A. Metode Pembuatan}

Dalam perancangan dan pembuatan produk ini digunakan model pengembangan prosedural yang bersifat deskriptif (Shodiq, 2005:32). Model ini adalah model pengembangan dengan mengikuti langkahlangkah sebagai berikut.

\section{Identifikasi Kebutuhan}

Pada tahap ini penulis mengidentifikasi kebutuhan akan produk ini dengan mengacu pada latar belakang masalah. Karena keterbatasan alat dan waktu penelitian maka identifikasi hanya dilakukan di teras depan Laboratorium IPA SMP Negeri 1 Lamongan. Dengan mengambil luas $(3 \times 3) \mathrm{m}^{2}$

\section{Pengembangan Produk}

Tahap pengembangan produk ini merupakan kegiatan mempersiapkan dan melaksanakan pembuatan produk keluaran. Pembuatan alat pendingin ruangan terbuka yang efektif, ekonomis dan ramah lingkungan, didasarkan pada tahapan identifikasi kebutuhan.

\section{Pengembangan Instrumen pengambilan data}

Instrumen pengambilan data yang digunakan adalah eksperimen. variabel yang diukur adalah suhu ruangan yang pada ruangan itu ditempatkan alat pendingin hasil pembuatan penulis. Sebelum alat dipasang suhu diukur telebih dahulu sebagai suhu awal. Kemudian suhu diukur setelah lima menit.

\section{B. Langkah-langkah Pembuatan}

Adapun langkah pembuatan alat pendingin udara ruangan terbuka adalah sebagai berikut.

1. Menyediakan sebuah kipas angin.

2. Kemudian melilitkan pipa tembaga di depan kipas.

3. Kemudian pipa tembaga diikatkan dengan kipas menggunakan tali (zipties).

4. Menggunting ujung-ujung tali (zipties) yang tidak terpakai .

5. Menyambung pipa tembaga dengan pipa plastik .

6. Menyediakan tandon air yang terbuat dari stirofom lalu melubangi kedua sisinya.

7. Memasukkan ujung pipa plastik ke dalam tandon stirofom melalui lubang yang sudah dibuat.
8. Menyediakan waterpump lalu menyambungkan ujung pipa plastik yang sudah dimasukkan ke dalam tandon stirofom dengan lubang keluaran water pump.

9. Memasukkan ujung pipa plastik yang lain ke dalam tandon stirofom melalui lubang yang sedah dibuat.

10. Mengisi stirofoam dengan air. (jika ingin lebih dingin bisa ditambahkan es dan garam krosok).

11. Menutup tandon stirofom.

12. Menyalakan kipas dan water pump.

13. Alat pendingin ruangan terbuka siap di gunakan.

\section{Cara Kerja alat pendingin ruang terbuka}

Cara kerja alat ini adalah dengan memanfaatkan konsep dasar fisika tentang perpindahan kalor. Yakni dengan meniupkan kalor yang terjadi di sekitar pipa tembaga ke daerah yang ada di sekitar kipas. Adapun cara kerja alat pendingin ruang terbuka dapat dilihat pada diagram alir berikut.

Penjelasan dari diagram di atas dapat dinyatakan sebagai berikut:

1. Air yang berada di dalam tandon di pompa ke pipa tembaga.

2. Air kemudian menuju pipa yang ada di depan kipas.

3. Saat air melewati pipa tembaga, maka suhu pipa tembaga akan menjadi dingin, begitu pula udara di sekitarnya akan menjadi dingin.

4. Udara dingin di depan kipas, kemudian di tiup oleh kipas ke daerah di depan kipas.

5. Sehingga ruangan di sekitar kipas akan menjadi dingin.

6. Air kemudian diteruskan kembali tandon.

7. Begitulah siklus alat pendingin udara ruang terbuka.

\section{HASIL DAN PEMBAHASAN}

Setelah melalui tahapan dalam persiapan dan langkah-langkah pembuatan didapatkan sebuah model alat pendingin ruang terbuka. Dikatakan sebuah model (prototipe) karena alat yang dikembangkan masih perlu disempurnakan lagi.

Rancangan alat pendingin ruang terbuka yang dikembangkan telah dibuat seefektif dan ekonomis mungkin.

Tabel 1. Daftar harga alat dan bahan rancangan pendingin ruang terbuka

\begin{tabular}{|c|c|c|c|}
\hline No & $\begin{array}{l}\text { Nama } \\
\text { Bahan }\end{array}$ & Jumlah & Harga \\
\hline
\end{tabular}




\section{Vol. 3 No. 1 Maret 2019}

\begin{tabular}{|c|l|c|c|}
\hline 1 & Kipas angin & 1 buah & 275.000 \\
\hline 2 & $\begin{array}{l}\text { Pipa } \\
\text { tembaga }\end{array}$ & $\begin{array}{c}4 \\
\text { meter }\end{array}$ & 67.000 \\
\hline 3 & $\begin{array}{l}\text { Selang } \\
\text { plastik }\end{array}$ & $\begin{array}{c}1 \\
\text { meter }\end{array}$ & 3.000 \\
\hline 4 & $\begin{array}{l}\text { Kotak } \\
\text { Stirofom }\end{array}$ & 1 buah & 24.000 \\
\hline 5 & Waterpump & 1 buah & 75.000 \\
\hline 6 & $\begin{array}{l}\text { Garam } \\
\text { krosok }\end{array}$ & $1 \mathrm{~kg}$ & 2.000 \\
\hline 7 & Zipties & 1 pack & 7.500 \\
\hline \multicolumn{3}{|c|}{ Jumlah } & 453.500 \\
\hline
\end{tabular}

Tabel 2. Daftar harga alat pendingin udara dari beberapa merk terkenal di pasaran

\begin{tabular}{|c|l|c|}
\hline $\begin{array}{c}\mathrm{N} \\
\mathrm{o}\end{array}$ & \multicolumn{1}{|c|}{$\begin{array}{l}\text { Nama } \\
\text { Barang }\end{array}$} & $\begin{array}{r}\text { Harga } \\
01.200 .0 \\
00\end{array}$ \\
\hline 1 & $\begin{array}{l}\text { Sharp air } \\
\text { cooler }\end{array}$ & $>1.249 .000$ \\
\hline 2 & $\begin{array}{l}\text { Sanyo air } \\
\text { cooler }\end{array}$ & $>3.957 .400$ \\
\hline 3 & $\begin{array}{l}\text { AC } \\
\text { Daikin }\end{array}$ & $>3.031 .300$ \\
\hline 4 & $\begin{array}{l}\text { AC } \\
\text { Panasoni } \\
\text { c }\end{array}$ & $>2.667 .500$ \\
\hline 5 & AC LG & $>2.859 .600$ \\
\hline 6 & $\begin{array}{l}\text { AC } \\
\text { Sharp }\end{array}$ \\
\hline
\end{tabular}

Pengembangan alat pendingin udara ruang terbuka ini juga memperhatikan dampak tehadap lingkungan. Sehingga selain dapat mendinginkan udara juga tidak berdampak negatif atau tidak menimbulkan efek terhadap lingkungan.

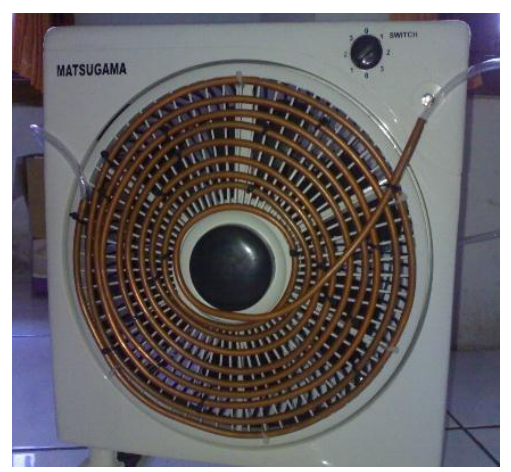

Gambar 1. Tampak depan alat pendingin udara ruang terbuka

\section{A. Temuan Lapangan}

Uji coba alat pendingin udara ruang terbuka dilakukan dengan cara menjalankan alat di daerah seluas $9 \mathrm{~m}^{2}$. Kemudian setelah lima menit suhu di depan alat diukur menggunakan termometer.

Pengamatan dilakukan pada tanggal

19 Oktober 2016 pukul 11.00 WIB di depan

Laboratorium IPA SMP Negeri 1 Lamongan.

Tabel 4.3. Hasil Pengamatan Uji Coba Alat

\begin{tabular}{|l|c|c|c|c|}
\hline $\mathrm{n}$ & $\begin{array}{c}\text { Pengambil } \\
\text { an data }\end{array}$ & $\begin{array}{c}\text { Suhu } \\
\text { awal } \\
\text { sebelu } \\
\text { m alat } \\
\text { dipasan } \\
\mathrm{g}\left({ }^{0} \mathrm{C}\right)\end{array}$ & $\begin{array}{c}\text { Suhu } \\
\text { setela } \\
\mathrm{h} \\
\text { lima } \\
\text { menit } \\
(\text { dala } \\
\mathrm{m}^{\mathrm{o}} \\
\mathrm{C}^{\circ}\end{array}$ & $\begin{array}{c}\text { Penurun } \\
\text { an suhu } \\
\text { (dalam } \\
\left.{ }^{0} \mathrm{C}\right)\end{array}$ \\
\hline 1 & 1 & 34 & 30 & 4 \\
\hline 2 & 2 & 33 & 30 & 3 \\
\hline 3 & 3 & 34 & 30 & 4 \\
\hline
\end{tabular}

\section{B. Analisis}

Dari spesifikasi alat dan bahan yang digunakan untuk membuat alat pendingin udara ruang terbuka pada tabel 1, biaya yang diperlukan untuk membuat alat ini sangat murah dibandingkan dengan harga pendingin udara yang ada di pasaran yaitu Rp 453.500,00. Pada tabel 4.2, harga pendingin udara baik jenis air cooler maupun AC rata-rata harganya di atas Rp 1.000.000,00. Sehingga alat ini dapat dikatakan ekonomis.

Dari temuan di lapangan dapat kita simpulkan bahwa alat pendingin udara ruang terbuka efektif dapat mendinginkan udara. Pada tabel 2, hal ini dibuktikan dengan adanya penurunan suhu $3^{0} \mathrm{C}$ sampai $4^{0} \mathrm{C}$. Penurunan itu disebabkan oleh udara dingin yang dihasilkan tembaga ditiup oleh kipas ke daerah di depan kipas. Akibatnya daerah di depan kipas menjadi dingin. Alat ini dibuat dari bahan yang tidak berbahaya (tidak menggunakan chlorofluorocarbons "CFC" dalam pendingin) sehingga dapat dikatakan sangat ramah terhadap lingkungan. Selain itu proses pembuatan alat yang sederhana menjadikan alat ini mudah dibuat sendiri di rumah.

Pipa tembaga dipilih karena tembaga dapat menjaga udara dingin dalam waktu yang lama. Sedangkan pemompa air dipasang bertujuan untuk membuat perputaran udara di dalam tembaga sehingga udara disekitar tembaga akan selalu tetap dingin. Jika tidak ada perputaran udara, udara di dalam tembaga semakin lama akan menjadi panas yang akan berakibat udara yang ditiup kipas juga panas.

\section{SIMPULAN}




\section{Vol. 3 No. 1 Maret 2019}

Dari hasil rancangan dan pengembangan alat pendingin ruang terbuka dapat disimpulkan bahwa alat pendingin ruang terbuka efektif dapat menurunkan suhu di sekitar pemasangan alat tersebut. Harga bahan penyusunnya yang murah dan tidak menimbulkan dampak negatif terhadap lingkungan menyebabkan alat ini dapat dikatakan ekonomis dan ramah lingkungan.

\section{A. Saran}

Berdasarkan kesimpulan penelitian ini, maka perlu disampaikan saran-saran sebagai berikut:

1. Bagi masyarakat hendaknya perlu mencoba alat pendingin ruang terbuka ini sebagai alternatif pendingin udara pada saat acara pesta di ruang terbuka.

2. Perlu dikembangkan alat yang lebih besar jika dibutuhkan untuk mendinginkan daerah yang luas.

3. Bagi peneliti berikutnya hendaknya dikembangkan alat yang lebih baik sebagai penyempurnaan dalam menurunkan suhu sehingga penurunan suhu akan semakin signifikan.

4. Perlu diadakan penelitian lebih lanjut tentang kombinasi penggunan panjang pipa, jenis pipa dan blower yang paling efektif.

\section{DAFTAR PUSTAKA}

Cenadi, S. C. 1999. Mengenal

PengkondisianUdara, Sebuah

Pengantar. Jakarta: PT. Grafindo

Persada.

Shodiq, Ja'far. 2005. Perancangan Kapasitas

Pengkondisian Udara di

Laboratorium Sistem Kontrol

Universitas Negeri Malang. Skripsi

tidak diterbitkan. Malang: Jurusan

Teknik Mesin FT UM.

http://id.wikipedia.org/wiki/AC, AC Sebuah

Pengantar, (Online) diakses 2 September 2016.

http://berhemat-

listrik.blogspot.com/2009/02/tip-

berhemat-listrik-untuk-ac-air.html,

(Online) diakses 3 September 2016.

http://www.astaga.com/forum/archive/index.ph p/t-1297.html, (Online) diakses 3

September 2016. 